\title{
Directions for Literacy Research: Analysing Language and Social Practices in a Textually Mediated World
}

\author{
David Barton \\ Department of Linguistics and Modern Language, Lancaster University, Bailrigg, \\ Lancaster LA 1 4YT, UK
}

This paper provides an overview of the field of Literacy Studies, describing the range of work which has been covered, identifying current unresolved issues as ways of suggesting future directions, and showing ways in which literacy can be seen as an integral part of the broader study of language. Various outstanding issues are discussed, including: the relation of print literacy to other media; questions of definitions and limits of what can be called literacy; what is meant by the key term practices and what are the components of practices; the relation of texts and practices; the relation of literacy theory to critical theory and social theory. One of the most salient aspects of contemporary life is change in communication technologies. Literacy Studies provides a way of understanding these changes by drawing attention to the changing materiality of language and by recasting the role of language in interaction. The paper concludes by arguing that much everyday activity in the contemporary world is mediated by literacy and that people act within a textually mediated social world. It is this textually mediated social world which Literacy Studies can continue to investigate, linking culture and cognition and analysing the dynamics of textually mediated communities of practice.

\section{Introduction}

In this paper I provide an overview of the field of Literacy Studies. I describe the range of work covered in Literacy Studies, identify current unresolved issues as ways of suggesting future directions and show ways in which Literacy Studies can be seen as an integral part of the broader study of language.

The field of Literacy Studies is now a substantial area of research. It is broad enough for there to be various disputes and unresolved issues within the field and there have been different traditions of research. My own work has been within one particular strand of Literacy Studies research; that of detailed investigations of literacy practices in particular situations. Literacy studies is broader; there are other studies with more interest in textual analysis, in other media, in critical theory and with stronger relations to policy and practice. Part of the coming of age of the field is the existence of different strands and discussions, disagreements and unconcluded business, as well as interest, support and attacks from beyond the field. Various issues have arisen from research such as ours, including its relation to other media, the limits of what can be called literacy, what is meant by practices, the relation of texts and practices, the importance of the materiality of texts. These form the basis for the ensuing discussion.

In this paper I concentrate on these conceptual issues. Inevitably, I start out from my own work and I cover issues of the definition of terms, including what is 
meant by literacies and practices; developments in methods; and the importance of theoretical framing. I argue that the framework provided by Literacy Studies of a textually mediated social world is essential for understanding and analysing contemporary changes in language use.

\section{The Development of Literacy Studies}

In many ways Literacy Studies grew out of a dissatisfaction with conceptions of reading and writing which were prevalent in education in all areas, from early childhood reading to adult literacy programmes: these were conceptions of reading and writing which were based on over-simplistic psychological models. The critique has been made from a range of disciplinary vantage-points and in a range of ways: it can be found in Giroux (1983), Willinsky (1990), Bloome and Green (1992), Gee (1990), Barton (1994), Baynham (1995), as well as in the work of Scribner and Cole (1981), Heath (1983) and Street (1984), which have become classic studies in the field. Willinsky talked of the 'New Literacy' and Gee (1990) first referred to the 'New Literacy Studies'. The critique of earlier views of literacy has been well rehearsed in these publications, opposing psychological approaches to language which fail to take account of social phenomena and critiquing inadequate educational views of literacy which do not look beyond pedagogy and the classroom.

Within education, Literacy Studies sometimes supports particular pedagogical practices (such as Willinsky's espousal of progressive education (1990), and the work on critical pedagogy (e.g. Giroux, 1983) while also going beyond a narrow focus on method (Bloome, 1987, 1989; Street \& Street, 1991; Cope \& Kalantzis, 2000) and making links with other domains (e.g. Taylor, 1983).

Beyond education, Literacy Studies has now established frameworks for investigating the nature of reading and writing in diverse areas, including everyday life (Barton \& Hamilton, 1998; Gregory \& Williams, 2000), religion (Kapitske, 1995), the workplace (Gowen, 1992; Hull, 1997), youth groups (Heath \& McLaughlin, 1993), prison (Wilson, 2000). Work covers a range of cultures (e.g. Street, 1993; Besnier, 1995; Prinsloo \& Breier, 1996) and historical periods (Cressy, 1980; Clanchy, 1993; Boyarin, 1993). Multilingual contexts are covered both within and beyond education (Moss, 1994; Gregory, 1996; Hornberger, 1997; Perez, 1998; Martin-Jones \& Jones, 2000). There are studies of gender, again within and beyond education (Millard, 1997; Cherland, 1994; Horsman, 1990; Finders, 1996; Luke, 1998; Mace 1998). Particular textual forms have been investigated, such as letters (Barton \& Hall 2000) and greetings cards (Jaffe, 1999). And there are concerns with new technologies (Tuman, 1992; Haas, 1996; Reinking et al., 1998; Snyder, 1998) including the Internet (Hawisher \& Selfe, 2000) and with social change (Kress, 1995; Luke, 1998).

Studies continue to cover a broad area and include work on topics which have traditionally been the province of psychological approaches to language, such as testing (as in Hill \& Parry, 1989) and language disorders (as in Parr, 1992). Work in Literacy Studies has led to a rethinking of student writing and a recasting of the field of study skills as academic literacies. (see Clark \& Ivanic, 1997; Ivanic, 1997; Candlin \& Hyland, 1999; Jones et al., 1999; Lea \& Stierer, 2000). There has been work in adult literacy (such as in Mace, 1995). In the field of adult literacy 
and development a reconceptualisation of literacy is leading to new approaches to education and development (Rogers, 1994, Rogers et al., 1999; Street, 2001; Rassool,1999). In areas where research has primarily focused on spoken interaction, such as the work-place, there is now work on written communication (Bargiela-Chiappini \& Nickerson, 1999).

Much of the work referred to here has developed independently of the parallel field of sociolinguistics; it tends not to be mentioned in sociolinguistics texts, which refer primarily to spoken language. Nevertheless, there is a strand of work which has drawn inspiration from sociolinguistics, including Heath's work, as well as Baynham (1993, 1995), Shuman (1996) and Tabouret-Keller et al. (1997); elsewhere I have discussed the potential inter-animation of Literacy Studies and sociolinguistics (Barton, 1998).

One of the aims of the empirical investigations of literacy has been to show the range and social patterning of practices. At the same time these studies have been developing the concepts. Studies such as Besnier's, (1995) demonstrate that social practices around literacy vary but, more fundamentally, that what is meant by the terms literacy, reading and writing differs across cultures. Furthermore, it is not just cross-culturally but within different contexts in the same culture, such as the home and the workplace and within the same activity, there can be different meanings of reading, writing and literacy.

The hallmark of much Literacy Studies research has been these detailed investigations of particular situations and this is the view-point from which I am assessing its achievements and dilemmas. In assessing what has been achieved, the work has come a long way from Stubbs' (1980: 164) plea for ethnographic studies and his hesitation in providing a theory of literacy at that point in time because so little was known about people's uses of literacy. (In fact the topics covered in his 1980 book can act as a useful benchmark, demonstrating the extent to which the field has broadened from its original focus on relations of written and spoken language, spelling, writing systems and reading failure.)

The success of Literacy Studies can be gauged by the fact that these critiques of earlier approaches have been taken seriously. The critiques have upset some cognitive psychologists studying reading who have returned the attack, often quite virulently, with a whole issue of a journal devoted to arguing against Literacy Studies (as in Gough and others' attack on Street's work, Gough, 1995); other examples of attacks are the argument between Taylor and Stanovich (Stanovich \& West, 1994) and Jones' attempt to write an obituary for Literacy Studies (1997). In turn, Literacy Studies has been defended against criticisms, as in Street (1996); this argument is likely to continue as part of a broader critique of narrow psychological paradigms and about appropriate methodologies for researching social phenomena.

The field of Literacy Studies has had some success and has been influential; it has provided a powerful research paradigm. However, at the level of policy and practice at this point in the British Government's changes in schools and its plans for adult literacy, it is hard to detect much influence of Literacy Studies on the national literacy strategy (see Hamilton \& Merrifield, 2000). Correspondingly, in the United States there are concerns about the lack of impact which contemporary research on literacy has on government policy (Taylor, 1998). 


\section{Questions of Definition}

In the research in which I have been involved we have carried out a detailed study of literacy practices in one town in England (Barton \& Hamilton, 1998). We looked at people's lives and how they used literacy in carrying out their daily activities. We found a variety of literacy practices in the home and community which overlap and intersect and which are rapidly changing. In many areas of life, in documenting life, when participating in social activity and in leisure pursuits we saw the importance of literacy and how people act within a textually mediated social world. This case study has been used to develop theory, to illuminate the results of broader surveys, for comparison with other contexts, and to counter deficit images of literacy in policy and practice. Such studies demonstrate the range of literacies in the community and the purposes to which it is put; they show that within a narrow area, such as home relations with school, a variety of literacy practices is drawn upon, and they also confirm the breadth of areas of life which utilise literacy. By studying the everyday, such studies shift the topic of literacy beyond being solely relevant to learning and assessment. Reflecting on this study and upon this approach to investigating literacy, of carrying out detailed case studies, in this section I want to identify some unresolved issues about the nature of literacy.

\section{Literacy and other media; Where does literacy end?}

Researchers agree that reading is increasingly one of a variety of ways in which people make sense of the world; and that people treat different media in an integrated way, not necessarily distinguishing reading print from other forms of sense making. Questions then arise about how to constrain the term literacy and whether researchers can and should include these other forms of meaning-making as part of literacy, as distinct literacies, or whether they are more usefully viewed as separable means of meaning-making which can distinguished from literacy. (This is one of several distinct uses of the plural term literacies.) In our own work we have argued for broad interpretations of what is meant by literacy and have accepted more fuzzy borders, in order to demonstrate links and similarities and we argue that they are not really separable; for example, one can then identify the similarities between book and film as mediated experiences. Similarly, people read timetables, maps and music, as well as novels and academic articles and there is a great deal in common in the practices associated with these diverse texts.

Others working within the area of Literacy Studies, such as Kress (2000), prefer a narrow definition of literacy in order to distinguish print literacy from other semiotic systems such as the visual. Linking different semiotic systems, Kress and van Leeuwen (1996) have developed an analysis of visual images which develops out of language analysis. Kress (1997) talks of multimodal meaning-making and that study, along with Hamilton (2000) and Stenglin and Iedema (2001), demonstrates the practical value of applying concepts developed in the study of language to visual images.

The issue of how far to extend the concept of literacy is not really resolved. This issue of needing both a broad and a narrow sense of literacy runs through the field, and, certainly from the beginning, Scribner \& Cole (1981: 236) were 
aware of this need. (The tension of working simultaneously with broad and narrow definitions is also found with the concepts of text, see later, genre, discourse, context and even with the concept of language itself.) Another aspect of this is the border between written and spoken language. The relationship is more complex than often characterised and, in fact, many complex ways of using spoken language have their roots in the written. In addressing this, Gee (1990), for example, is less concerned with whether something is written or spoken, preferring to talk of secondary discourses, ones which are more specialised and more likely to be deliberately learned. This is a first step in situating the study of literacy practices within linguistics and alongside the study of discourse. These questions are of contemporary relevance as new technologies are changing the landscape of language practices.

\section{The components of practices}

What are the units of analysis which Literacy Studies utilises? The notion of literacy practices has been central to this work and has been of value as an overarching concept. People use the term literacy practices to refer to the general cultural ways of utilising literacy which people draw upon in particular situations (see discussion in Barton, 1994: 36-7; Baynham, 1995; Street, 2000). One needs to go further and examine what constitutes a practice. Originally Scribner and Cole (1981) referred to knowledge, skills and technologies as the components of practices in a framework which was still basically cognitive and which seemed to see the social as a separable influence on the cognitive. Contemporary work on communities of practice has developed from Scribner \& Cole's original work and in the research over the past two decades associated with Jean Lave and Etienne Wenger one can trace a progression from a psychological model with the social as a context developing into a model which is essentially socio-cultural. In particular, the notion of communities of practice provides a set of concepts which view learning as a form of participation in activities. This development can be clearly seen in the books which have been published in this period: Rogoff and Lave (1984); Lave (1988); Lave and Wenger (1991); Chaiklin and Lave (1993); Wenger (1998). Each of these books develops the concept of practices and the notion of communities of practices articulated most recently in Wenger (1998) can be of value and complement work in Literacy Studies in the ways in which it describes learning in certain sorts of groups. Understanding the strengths and limitations of this concept and its similarities to and distinctiveness from notions of speech community (as in Holmes \& Meyerhoff, 1999; Eckert, 2000) and, more crucially, discourse community should prove revealing.

Literacy studies began partly as a reaction to broad generalisations about literacy and claims of a great divide between oral and literate, both socially and cognitively. As a result of this, researchers in Literacy Studies have been very cautious about grand claims for literacy and have been hesitant about examining the mental work literacy can do. Probably both sides in this original argument have shifted towards each other (e.g. Olson, 1994). Nevertheless, a tension still remains between stressing the significance of the written word and the literate world while at the same time denying its uniqueness and universality (see also Harris, 1995). It may be time to return to these issues: through developments in situated learning and ideas about communities of practice, it may be possible to 
begin to re-articulate the role of literate activity in a redefined cognition and to be clearer about the sort of generalisations across situations we want to make about literacy practices. Such developments may provide a metalanguage for talking about learning and cognition in a more fruitful way.

A further area where the notion of practices has been of value has been within anthropological linguistics, as in Hanks (1996) and Duranti (1997). This work, like most anthropological work, starts out from spoken language practices. It identifies a clear set of concepts for analysing practices and, again, Literacy Studies could utilise these concepts, as well as contributing to this area of linguistics by demonstrating the distinctiveness of the forms and functions of written language. In work at Lancaster we have begun to investigate the components of practices by keeping close to the empirical investigation of literacy practices (Barton \& Hamilton, 1998; Barton et al., 2000). Hamilton (2000), for instance, refers to texts, participants, settings and artefacts in the analysis of newspaper photographs and the same framework has been applied to letter writing as a social practice (Barton \& Hall, 2000). This then needs to be set in broader discussions of social practices, drawing upon both anthropology and social theory.

One of the reasons for analysing practices in a detailed way is to identify the distinctiveness of literacy in different domains. Everyday life, school and work-place, for example, are often contrasted in their practices. As previously reviewed, there are now studies in particular domains. The issue is how to put the studies together. These domains may be different; one task now is to identify what they have in common and what is distinct about practices in different domains. This is all happening in a context where domains are more fluid and where practices are more hybrid.

\section{Critical literacy and the role of social theory}

Inevitably, there is no clear line between what work counts as being part of Literacy Studies and what represents a distinctive approach. Also, theorists may not identify with the phrase 'Literacy Studies'. One strand is the work associated with Giroux and others which draws inspiration from Critical Theory. Some of those working in Critical Literacy see this as being part of Literacy Studies (as in Luke, 1998), while others see it as a separate field of work which can be contrasted with Literacy Studies (as in Auerbach, 1997). See also Street (1998) and Coffin (2001) for different contrasts. Any differences are partly based upon a different method of approach; in our own work we have an emphasis on ethnographic and other qualitative methods, drawing on detailed case studies. This is part of a broader issue of the significance of theory in these approaches and of the relation of Literacy Studies to other areas of linguistics such as work on genre, systemic linguistics and critical discourse analysis.

There have been leaps in the understanding of society and culture across many disciplines with social theory reaching most areas of social science research. In fact, in the social-theory-influenced world of today it is hard to distinguish psychological and sociological approaches to language; there is a new fluidity, where psychologists are influenced by social theory whilst sociologists and social theorists are grappling with subjects which have traditionally been the preserve of psychology, such as the nature of identity, self, subjectivity and experience. 
We believe that a strength of Literacy Studies is that it can combine a very strong empirical tradition with frameworks from social theory and that it can draw upon a broader range of areas of social theory than just critical theory. For example, in Barton et al. (2000) the studies draw upon work on globalisation, time, identity, science studies and more. We believe that to address its social aims the study of language needs theories about topics such as how the media works; the relationship between local detail and global activity; notions of self and identity; social and technological change; the shift from modern to post-modern. Contemporary studies of literacy can work within these frameworks, partly drawing upon them, but also creating them. It can take advantage of developments in theorising social practices, as in Chouliaraki and Fairclough, (1999).

An additional task is to link in a motivated way research which starts with the analysis of texts with research which sets out from the analysis of practices. These have been quite different traditions of research: discourse analysis studies have analysed texts and much Literacy Studies research has been of practices. The difficulty is to link these in a way which shows the mutual influences of the texts and the practices. Contributors to Cope and Kalantzis (2000) have begun to do this, as have Ormerod and Ivanic (2000). Texts and practices come together where Williams (1998: 20) and others talk of textual practices, referring to the language choices within texts; here textual practices are one element of social practices, complemented by the practices associated with the creation and use of texts.

\section{Understanding the Future}

One of the most obvious aspects of contemporary life is change. Life is changing and language is changing. Understanding the future is about understanding literacies and their shifting role (as people such as Kress, 1995, 2000, Gee et al., 1996, and Lankshear 1997 are beginning to articulate). This section examines the distinct contribution which Literacy Studies can make to this discussion.

\section{The material world}

Literacy Studies provides a way of understanding that writing is more than spoken language written down and that the term literacy embraces more than the acts of reading and writing. This approach enables the discussion to move beyond both the traditional formulations of both sociolinguistics and psycholinguistics. On the one hand, sociolinguistics, as portrayed in textbooks and handbooks, has focused primarily on spoken language (see Barton, 1998). However, the physical existence of texts makes their study different from sociolinguistic studies of how, where and when spoken language is used. From another direction, for some, especially psycholinguists, written language is language made visible. Here the visual characteristics of language are investigated; but this can be taken further, since in written texts language is also made physical. Both of these approaches still have underlying them an impoverished view of written language: this is the idea that written language is just speech written down.

The significance of the material existence of written language was apparent in the local literacies research, where such disparate factors as the physical exis- 
tence of books on shelves, the displays on notice-boards and texts on clothing were all acts of meaning-making. In addition, Ormerod and Ivanic (2000), studying children's homework projects, and Wilson (2000), studying prisoners' literacy practices, have drawn attention to the importance of the materiality of texts in very different situations. The physical nature of the text is one aspect of this materiality. Another salient aspect of materiality is the existence of the range of cultural artefacts associated with literacy (see Graddol, 1994; Hall, 2000). (Of course, spoken language has a materiality; what is important is the changing materiality in different forms of language.) One significant aspect is that because of its materiality, written language has a different relationship to context from much spoken language, and often its importance is in how it is contextualised and recontextualised; this is particularly relevant within the sphere of education.

The contemporary interest in materiality arises, and maybe even originates, in studies of computing where, compared with paper, the materiality of texts changes so much, as discussed in Haas (1996). The new configurations of language use developing with technologies render impossible the simplistic distinctions between written and spoken language. Understanding the language of internet chat, for example, or mobile phone use, or text messaging is more complex than analysing the language and attempting to classify it on a dimension from spoken to written. These are new forms of communication, with new forms of language and new practices. The practices around the texts and the technologies are an integral part of the language (see, for example, Miller \& Slater, 2000). Materiality has also been investigated from a different direction by those interested in the book as an object, considering its importance as a material object and the contribution of materiality to processes of reading and understanding (as in Moylan \& Stiles, 1996; Nunberg, 1999).

\section{Texts in interaction}

Sociolinguistic research on interaction has primarily been of spoken language and of face-to-face interaction. Literacy Studies broadens the notion of interaction by focusing on the importance of texts and examining the various roles texts have in interaction. It broadens the focus from spoken language and from face-to-face interaction. The original notion of literacy event grew out of work on speech events, with the idea of a literacy event being a speech event with a text in it (as in the early work of Heath, 1983:236); the talk around a text is the classic literacy event (and see Graddol, 1994 on different definitions of the term text).

However, there are other sorts of literacy event, where texts are present but are not read in a conventional sense; there are events where texts have symbolic functions; and there are various ways in which texts which may or may not be present are invoked. Events vary in the role of the text: the text can be central, as in the act of reading instructions from a manual; the text can be symbolic, as when swearing on the Bible; and the text can be implicit, as when talking about texts which are not present. Consequently, within Literacy Studies there has been a broadening of the notion of literacy event; the concept can be expanded from one which focuses on talk around a text, such as the mother and child story-time, to one that includes talk about a text, such as a discussion of a previously read magazine, to not containing talk, such as holding a placard at a demonstration, see later. Similarly, there are many relations between events: events can be serial, 
coordinated and chained; they can be embedded or subordinated; they can be fuzzy.

Alongside these broadening definitions there is evidence that the existence of texts in events changes things: interaction around a text is different. First, talk around texts is important in several ways. To give a range of examples, with children's book reading, there is evidence that talk around texts can be much richer for learning (Snow, 1983). Baynham (1993) has examined the way people go back and forth between text and talk, which he refers to as mode-switching. There is also research on the importance of bilingual talk around monolingual texts in the community and in the classroom (Martin-Jones \& Jones, 2000). Second, even when there are no texts lurking in the event, texts can be the subject of the talk: people talk about texts. As the work of Maybin and Moss (1993) and Jones (2000) demonstrates, much talk is about texts. Much of the 'language as spoken by ordinary people in their everyday lives', the focus of most sociolinguistics research, is in fact talk about texts. It can be revealing then to move to the position that most speech events in contemporary society are, in a broad sense, literacy events.

\section{A textually mediated social world}

One of the main points of our Local Literacies research and other detailed studies of literacy in specific contexts is that much social life is mediated by literacy. We found that in the various areas of everyday life which we studied, such as communication, organising life, leisure activities and social participation, people's activities were mediated by literacy. We found that we had been studying a textually mediated everyday life, not one held together solely by spoken language. We concluded that nearly all everyday activities in the contemporary world are mediated by literacy and that people act within a textually mediated social world. It is this textually mediated social world which Literacy Studies itself can continue to investigate, linking culture and cognition and analysing the dynamics of textually mediated communities of practice.

The critique this provides of dominant sociolinguistics research is similar to the critique which Dorothy Smith has made of sociology. She accuses sociology of being extraordinarily blind to the phenomenon of textually mediated communication, action and social relations ... Our lives are infused with a process of inscription, producing written or printed traces or working from them' (Smith, 1990: 209). She continues

The appearance of meaning as a text detaches meaning from the lived processes of its transitory construction, made and remade at each moment of people's talk. The vesting of meaning in such permanent or semi-permanent forms is routine and commonplace, and has transformed our relations to language, meaning and each other' (pp. 210-11)

See also Smith, 1999: 219-20.

The underlying issue here is that writing is not just speech written down, it is a different form of language, a distinct form of meaning-making. This is one of the basic original points of Literacy Studies (as in Stubbs, 1980), a point which still needs to be argued and elucidated (as Harris, 1995, for example, has done). The fact that people live and act in a textually mediated world is the issue which 
makes the frameworks provided by Literacy Studies so essential for the more general study of language. Research which sets out from face-to-face spoken language interaction has difficulty in addressing other aspects of social life which are mediated by texts, including areas such as computing and new technologies. Whether it is technological change and Internet use, educational change and the nature of learning, the relation of language to poverty and social exclusion, or language in the changing work-place, an analysis which starts from literacies is central to understanding. Studies restricted to spoken language cannot adequately account for these crucial areas of contemporary language use.

In conclusion, to bring the various strands of this paper together, there is now a considerable body of work in Literacy Studies and there are many areas to continue to investigate. Issues of the elucidation of concepts and the development of methods and theoretical framing remain. Nevertheless, Literacy Studies provides a paradigm which is essential in the study of contemporary language use and how it is changing in the textually mediated social world we inhabit. This work is an essential component of a redefined linguistics, the study of texts and practices.

\section{Correspondence}

Any correspondence should be directed to Prof. David Barton, Department of Linguistics and Modern English Language, Lancaster University, Lancaster LA1 4YT, UK.

\section{References}

Auerbach, E. (1997) Reading between the lines. In D. Taylor (ed.) Many Families, Many Literacies (pp. 69-71). Portsmouth, NH: Heinemann.

Bargiela-Chiappini and Nickerson (eds) (1999) Writing Business. London: Longman.

Barton, D. (1994) Literacy: An Introduction to the Ecology of Written Language. Oxford: Blackwell.

Barton, D. (1998) Is Literacy Studies re-inventing sociolinguistics? Paper presented at Sociolinguistics Symposium, London, March.

Barton, D. and Hall, N. (eds) (2000) Letter Writing as a Social Practice. Amsterdam: John Benjamins.

Barton, D. and Hamilton, M. (1998) Local Literacies: Reading and Writing in One Community. London: Routledge.

Barton, D., Hamilton, M. and Ivanic, R. (eds) (2000) Situated Literacies: Reading and Writing in Context. London: Routledge.

Baynham, M. (1993) Code switching and mode switching: Community interpreters and mediators of literacy. In B. Street (ed.) Cross-cultural Approaches to Literacy. Cambridge: Cambridge University Press.

Baynham, M. (1995) Literacy Practices. London: Longman.

Besnier, N. (1995) Literacy, Emotion and Authority: Reading and Writing on a Polynesian Atoll. Cambridge: Cambridge University Press.

Bloome, D. (ed.) (1987) Literacy and Schooling. Norwood, NJ: Ablex.

Bloome, D. (ed.) (1989) Literacy and Classrooms. Norwood, NJ: Ablex.

Bloome D. and Green, J.L. (1992) Educational contexts of literacy. Annual Review of Applied Linguistics 12, 49-70.

Boyarin, J. (ed.) (1993) The Ethnography of Reading. University of California Press.

Candlin, C. and Hyland, K. (1999) Writing: Texts, Processes and Practices. London: Longman.

Chaiklin, S. and Lave, J. (eds) (1993) Understanding Practice: Perspectives on Activity and Context. Cambridge: Cambridge University Press. 
Cherland, M. (1994) Private Practices: Girls Reading Fiction and Constructing Identity. London: Taylor and Francis.

Chouliaraki, L. and Fairclough, N. (1999) Discourse in Late Modernity. Edinburgh: Edinburgh University Press.

Clanchy, M.T. (1993) From Memory to Written Record. Oxford: Blackwell.

Clark, R. and Ivanic, R. (1997) The Politics of Writing, London: Routledge.

Coffin, C. (2001) Theoretical approaches to written language. In A. Burns and C. Coffin (eds) Analysing English in a Global Context (pp. 93-122). London: Routledge.

Cope, B. and Kalantzis, M. (eds) (2000) Multiliteracies: Literacy Learning and the Design of Social Futures. London: Routledge.

Cressy, D. (1980) Literacy and the Social Order: Reading and Writing in Tudor and Stuart England. Cambridge: Cambridge University Press.

Duranti, A. (1997) Linguistic Anthropology. Cambridge: Cambridge University Press.

Eckert, P. (2000) Linguistic Variation as Social Practice. Oxford: Blackwell.

Finders, M.J. (1996) Just Girls. New York: Teachers Press.

Gee, J., Hull, G. and Lankshear, C. (1996) The New Work Order: Behind the Language of the New Capitalism. London: Allen and Unwin.

Gee, J. (1990) Social Linguistics and Literacies (2nd edn 1996) London: Falmer Press.

Giroux, T.H. (1983) Theory and Resistance in Education: A Pedagogyfor the Opposition. Bergin and Garvey.

Gough, P. (1995)The New Literacy: Caveat Emptor. Journal of Researchin Reading 18,79-86.

Gowen, S.G. (1992) The Politics of Workplace Literacy: A Case Study. New York: Teachers College Press.

Graddol, D. (1994) What is a text? In D. Graddol and O. Boyd-Barrett (eds) Media Texts: Authors and Readers (pp. 40-50). Clevedon: Multilingual Matters.

Gregory, E. (1996) Making Sense of a New World: Learning to Read in a Second Language. Paul Chapman.

Gregory, E. and Williams, A. (2000) City Literacies: Learning to Read Across Generations and Cultures. London: Routledge.

Haas, C. (ed.) (1996) Writing Technology: Studies on the Materiality of Literacy. Mahwah, NJ: Lawrence Erlbaum.

Hall, N. (2000) The materiality of letter writing: A nineteenth century perspective. In D. Barton and N. Hall (eds) Letter Writing as a Social Practice (pp. 83-108). Amsterdam: John Benjamins.

Hamilton, M. (2000) Expanding the new Literacy Studies: Using photographs to explore literacy as social practice. In D. Barton, M. Hamilton and R. Ivanic (eds) Situated Literacies: Reading and Writing in Context (pp. 16-34). London: Routledge.

Hamilton, M., Barton, D. and Ivanic, R. (eds) (1994) Worlds of Literacy. Clevedon: Multilingual Matters.

Hamilton, M. and Merrifield, J. (2000) Adult basic education in the UK. Lessons for the US. National Review of Literacy 1 (1). National Center for the Study of Adult Language and Literacy.

Hanks, W. (1996) Language and Communicative Practices. Boulder: Westview Press.

Harris, R. (1995) Signs of Writing. London: Routledge.

Hawisher, G. and C. Selfe (eds) (2000) Global Literacies and the World-wide Web. London: Routledge.

Heath, S. (1983) Ways with Words: Language, Life and Work in Communities and Classrooms. Cambridge: Cambridge University Press.

Heath, S. and McLaughlin, M. (eds) (1993) Identity and Inner-city Youth: Beyond Ethnicity and Gender. New York: Teachers College Press.

Hill, C. and Parry, K. (1989) Autonomous and pragmatic models of literacy: Reading assessment in adult education. Linguistics and Education 1, 233-83.

Holmes, J. and Meyerhoff, M. (1999)The community of practice: Theories and methodologies in language and gender research. Language in Society 28, 173-83.

Hornberger, N.H. (ed.) (1997) Indigenous Literacies in the Americas: Language Planning from the Bottom Up. Berlin: Mouton de Gruyter.

Horsman, J. (1990) Something on My Mind Besides the Everyday. Toronto: Women's Press. 
Hull, G. (ed.) (1997) Changing Work, Changing Workers:Critical Perspectives on Language, Literacy, and Skills. State University of New York Press.

Ivanic, R. (1997) Writing and Identity. Amsterdam: John Benjamins.

Jaffe, A. (1999) Packaged sentiments: The social meanings of greetings cards. Journal of Material Culture 4, 115-41.

Jones, C., Turner, J. and Street, B. (eds) (1999) Student Writing in the University. Amsterdam: John Benjamins.

Jones, K. (2000) Becoming just another alphanumeric code: Farmers' encounters with the literacy and discourse practices of agricultural bureaucracy at the livestock auction. In D. Barton, M. Hamilton and R. Ivanic (eds) Situated Literacies: Reading and Writing in Context (pp. 70-90). London: Routledge.

Jones, S. (1997) Ending the myth of the 'literacy myth'. Literacy Across the Curriculum 12 (4), 10-17. Montreal: Centre for Literacy.

Kapitske, C. (1995) Literacy and Religion: The Textual Politics and Practice of Seventh-Day Adventism. Amsterdam: John Benjamins.

Kress, G. (1995) Writing the Future: English and the Making of a Culture of Innovation. Sheffield: NATE.

Kress, G. (1997) Before Writing. London: Routledge.

Kress, G. (2000) The Futures of Literacy. Rapal Bulletin 42, 1-19.

Kress, G. and van Leeuwen, T. (1996) Reading Images: The Grammar of Visual Design. London: Routledge.

Lankshear, C. (with others) (1997) Changing Literacies. Buckingham: Open University Press.

Lave, J. and Wenger, E. (1991) Situated Learning: Legitimate Peripheral Participation. Cambridge: Cambridge University Press.

Lave, J. (1988) Cognition in Practice. Cambridge: Cambridge University Press.

Lea, M. and Stierer, B. (eds) (2000) Student Writing in Higher Education. Buckingham: Open University Press.

Luke, A. (1998)Critical approaches to literacy. In V. Edwards and D. Corson (eds) Encyclopedia of Language and Education. Volume 2, Literacy. Dordrecht: Kluwer.

Mace, J. (ed.) (1995) Literacy, Language and Community Publishing. Clevedon: Multilingual Matters.

Mace, J. (1998) Playing with Time: Mothers and the Meaning of Literacy. London: UCL Press.

Martin-Jones, M. and Jones, K. (eds) (2000) Multilingual Literacies. Amsterdam: John Benjamins.

Maybin, J. and Moss, G. (1993) Talk about texts: Reading as a social event. Journal of Research in Reading 16, 138-47.

Millard, E. (1997) Differently Literate. London: Falmer Press.

Miller, D. and Slater, D. (2000) The Internet: An Ethnographic Approach. Oxford: Berg.

Moss, B.J. (1994) Literacy Across Communities. Creshill, NJ: Hampton Press.

Moylan, M. and Stiles, L. (1996) Reading Books: Essays on the Material Text and Literature in America. Amherst: University of Massachusetts Press.

Nunberg, G. (ed.) (1999) The Future of the Book. University of California Press.

Olson, D. (1994) The World on Paper. Cambridge: Cambridge University Press.

Ormerod, F. and Ivanic, R. (2000) Texts in practices: Interpreting the physical characteristics of children's project work. In D. Barton, M. Hamilton and R. Ivanic (eds) Situated Literacies: Reading and Writing in Context (pp. 91-107). London: Routledge.

Parr, S. (1992) Everyday reading and writing practices of normal adults: Implications for aphasia assessment. Aphasiology 6, 273-83.

Perez, B. (ed.) (1998) Sociocultural Contexts of Language and Literacy. Mahwah, NJ: Lawrence Erlbaum.

Prinsloo, M. and Breier, M. (1996) The Social Uses of Literacy: Theory and Practice in Contemporary South Africa. Amsterdam: John Benjamins.

Rassool, N. (1999) Literacy for Sustainable Development in the Age of Information. Clevedon: Multilingual Matters.

Reinking, D., McKenna, M., Labbo, L. and Kieffer, R. (eds) (1998) Handbook of Literacy and 
Technology: Transformations in a Post-typographic World. Mahwah, NJ: Lawrence Erlbaum.

Rogers, A. (1994) Using Literacy: A New Approach to Post-literacy Materials. ODA Occasional Paper on Education 10. London: Overseas Development Agency.

Rogers, A., Maddox, B., Millican, J., Newell Jones, K., Papen U., and Robinson-Pant, A. (1999) Redefining Post-literacy in a Changing World. Occasional Paper on Education 29. London: Department for International Development.

Rogoff, B. and Lave, J. (1984) Everyday Cognition: Its Development in Social Context. Cambridge, MA: Harvard University Press.

Scribner, S. and Cole, M. (1981) The Psychology of Literacy. Cambridge, MA: Harvard University Press.

Shuman, A. (1986) Story Telling Rights: The Uses of Oral and Written Texts by Urban Adolescents. Cambridge: Cambridge University Press.

Smith, D. (1990) Texts, Facts and Femininity. London: Routledge.

Smith, D. (1999) Writing the Social: Critique, Theory and Investigations. Toronto: University of Toronto Press.

Snow, C. (1983) Literacy and language: Relationships during the pre-school years. Harvard Educational Review 55, 165-89.

Snyder, I. (ed.) (1998) From Page to Screen: Taking Literacy into the Electronic Era. London: Routledge.

Stanovich, K. and West, R. (1994) Reply to Taylor. Reading Research Quarterly 29, 290-1.

Stenglin, M. and Iedema, R. (2001) How to analyse visual images: A guide for TESOL teachers. In A. Burns and C. Coffin (eds) Analysing English in a Global Context (pp.194-208). London: Routledge.

Street, B. (1984) Literacy in Theory and Practice. Cambridge: Cambridge University Press.

Street, B. (ed.) (1993) Cross-cultural Approaches to Literacy. Cambridge: Cambridge University Press.

Street, B. (1996) Preface. In M. Prinsloo and M. Breier (eds) The Social Uses of Literacy: Theory and Practice in Contemporary South Africa. Amsterdam: John Benjamins.

Street, B. (1998) New literacies in theory and practice: What are the implications for education? Linguistics and Education 10, 1-24.

Street, B. (ed.) (2000) Literacy events and literacy practices. In Martin-Jones and Jones (eds) Multilingual Literacies. Amsterdam: John Benjamins.

Street, B. (ed.) (2001) Literacy and Development. London: Routledge.

Street, J.C. and Street, B. (1991) The schooling of literacy. In D. Barton and R. Ivanic (eds) Writing in the Community (pp. 143-66). London: Sage.

Stubbs, M. (1980) Language and Literacy. London: Routledge and Kegan Paul.

Tabouret-Keller, A., Le Page, R., Gardner-Chloros, P. and Varro, G. (eds) (1997) Vernacular Literacy: A Re-evaluation. Oxford: Clarendon Press.

Taylor, D. (1983) Family Literacy. London: Heinemann Educational.

Taylor, D. (1998) Beginning to Read and the Spin Doctors of Science. Urbana: NCTE.

Tuman, M. (1992) Word Perfect: Literacy in the Computer Age. London: Falmer Press.

Wenger, E. (1998) Communities of Practice. Cambridge: Cambridge University Press.

Williams, G. (1998) Children entering literate worlds: Perspectives from the study of textual practices. In F. Christie and R. Mission (eds) Literacy and Schooling. London: Routledge.

Willinsky, J. (1990) The New Literacy. London: Routledge.

Wilson, A. (2000) There is no escape from third-space theory: Borderland discouse and the 'In-between' literacies of prisons. In D. Barton, M. Hamilton and R. Ivanic (eds) Situated Literacies: Reading and Writing in Context (pp. 54-69). London: Routledge. 